\title{
The World Bank's Role in Tourism Development: The Case of Uzbekistan
}

\author{
Prof. Dr. Mithat Zeki Dinçer (İstanbul University, Turkey) \\ Prof. Dr. Fatma Füsun İstanbullu Dinçer (İstanbul University, Turkey) \\ Ph.D. Candidate Zaid Alrawadieh (İstanbul University, Turkey)
}

\begin{abstract}
After the collapse of the former Soviet Union, Uzbekistan started to build its own national economy with serious attempt to integrate with the international economy. Right after the independence, Uzbekistan joined the international organizations such the World Bank and the United Nations World Tourism Organization. Development projects were initiated and radical changes were noted through developing the infrastructure and building new airports and railways. Tourism was considered a priority and a tool for development in Uzbekistan. With these thoughts in mind, this paper attempts to examine the World Bank's role in the tourism development in Uzbekistan. For the purpose of this study, the bank's documents related to 39 projects that were implanted or are being currently implemented in the country were reviewed and content analyzed. The study suggested that, since the independence of Uzbekistan in 1991 and its enrollment to the World Bank in 1992 there has been no tourismfocus projects supported by the bank. Yet, a number of projects that addressed areas such as urban development and human resources development are expected to affect indirectly the growth and development of tourism industry in the country. The paper recommends tourism planners in Uzbekistan to reevaluate their connections with the international organizations to maximize their role in lunching projects that would contribute to the tourism development in the country.
\end{abstract}

\section{Introduction}

During the former Soviet Union, Uzbekistan was a major tourist destination connected with the Moscow-based organizations. After the independence in 1991, the country started to build its own independent tourist product. The political instability, the economic problems and the major changes following the collapse of the Soviet Union were among the major difficulties in the face of the tourism development (Airey and Shackley, 1997). Yet, 3 years after the independence, Uzbekistan became a member-state in the United Nations World Tourism Organization (UNWTO) and tourism was considered one of the ten priorities included in the government's investment program (Centre for Cooperation with European Economies in Transition, 1996). The national company "Uzbektourism" was founded in 1992 to be the first state body acting not only as tourism promotion agency but also operating the country's main hotels.

There is a common consensus that tourism is a passport to development (de Kadt, 1979) specially for small economies (Ayres, 2000). The international organizations acknowledge the pivotal role of tourism activity in countries' economic growth and development. In Uzbekistan, the richness of cultural heritage and historical sites was recognized and many restoration projects were funded by overseas sources such as Arab league and UNESCO (Airey and Shackley,1997). One of the global organizations that acknowledged, in an early stage, the role of tourism as a development tool was the World Bank.

With these thoughts in mind, this paper aims at examining the World Bank's role in tourism development in Uzbekistan. For the purpose of this study, all the development projects supported by the World Bank were reviewed and content analyzed to gain insights on the World Bank's role in enhancing tourism development in the central Asian Ex-Soviet state. Since the independence of Uzbekistan from the former Soviet Union, the World Bank supported and funded 39 projects in the country. of these 39 projects, 21 projects are currently being implemented (active) whereas the rest are accomplished (closed). Documents related to these projects and made available on the World Bank's official website were analyzed. Results are discussed throughout the following sections.

\section{Tourism Development in Uzbekistan}

The Stalin's 1924 borders made today's Uzbekistan the home of the most important central Asian historical monuments (Kurzman, 1999), including the UNESCO World Heritage Listed cities of Khiva, Bukhara, Shakhrisyabz and Samarkand. These sites constitute the core of tourism product in the country (Baum and Thompson, 2007). The richness of the historical, archeological and ecological attractions along the Ancient Silk Road is a source of wealth that can offer real opportunities for development and economic growth in Uzbekistan (Kantarci, 2007a).

According to the figures of the World Travel and Tourism Council (WTTC), the direct contribution of Uzbekistan tourism sector to Gross Domestic Product (GDP) is $0.9 \%$ (World Travel and Tourism Council, 2015). Tourism industry in Uzbekistan created a total of 387.500 jobs, that is, 2.6 of the total employment. By 2025, the number of jobs is expected to reach about 570.000 jobs. The figures indicate that tourism exports account for 1.6 of the 
total exports in 2014. The percentage of tourism exports of the total exports is forecast to be stable over the period 2015-2025 (World Travel and Tourism Council, 2015). Although the contribution of tourism in Uzbekistan national economy seems to be modest in the current time, yet, if the existing opportunities and potential are to be properly used and tourism investment is enhanced, the sector will be an important income-generating sector in the future (Kantarci, 2007a).

It seems to be difficult to obtain reliable data related to the numbers of international arrivals to Uzbekistan prior to its independence from the former Soviet Union. However, the number of tourists to Uzbekistan was estimated to have reached about 288.000 in 1980 and doubled in 1995 (Agzamov \& Tashmuratov 1995, as cited in Airey and Shackley, 1997).

As depicted in figure 1, the number of international arrivals was about one million in 1997 whereas over the following 8 years the number declined registering only 242.000 tourists in 2005 . The number increased gradually between 2006-2009 but declined again 2010 presumably as a consequence of the international economic crisis. In 2013 (the most recent available data), the number of tourists visiting Uzbekistan is only one step away from 2 million.

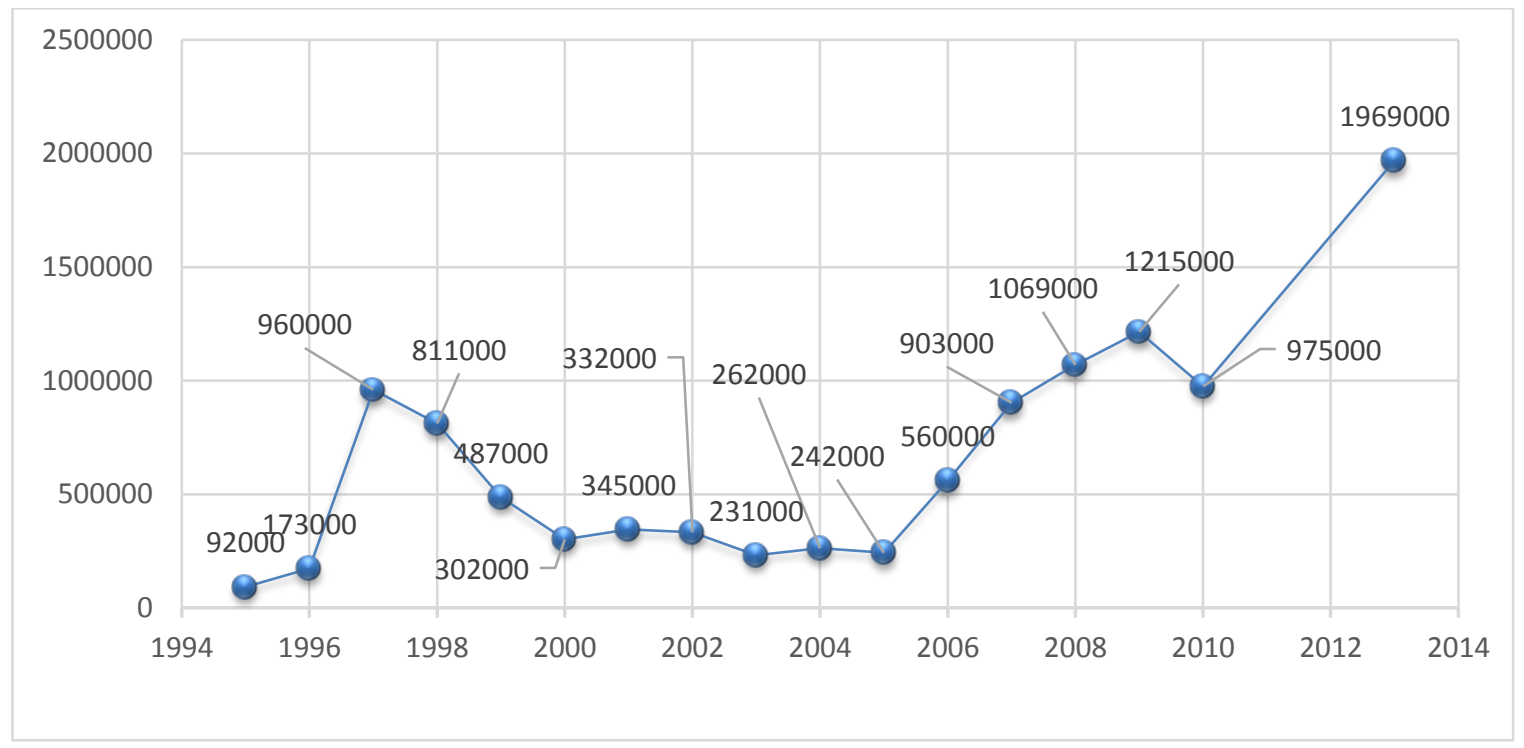

Figure 1. The Number of International Arrivals as to Uzbekistan (1995-2013) Source: World Bank (2016a)

* Number of arrivals for the years 2011 and 2012 is unavailable.

Considering the population of Uzbekistan (over 30 million) and the potential tourist attractions in the country, the current indicators of the tourism sector rise the urgent need to exercise more efforts to promote the Uzbek tourist destinations and adopt adequate strategies to maximize the tourism exports. Like the other Central Asian countries, Uzbekistan's share of the international tourism market is considered to be very marginal, according to Kantraci (2007b), Uzbekistan, as a tourism destination, suffers from the lack of a strong image that would motivate world travelers to visit. In addition, bureaucracy is considered one of the potential obstacles in the face of tourism development in the country (Kapiki and Tarikulov, 2014, Sancar, Kıngır, and Soyalın, 2015). Although the country has a number of significant attractions and adequate services, transformation of tourism seems to be infantile (Airey and Shackley, 1997).

One of the issues that may discourage international travelers to choose Uzbekistan as a tourism destination may be related to the uneasy accessibility to the country. Entry barriers may need to be reduced through modifying the visa issuing procedures. According to the Uzbek tourism official promotional website, only citizens of Kyrgyzstan, Armenia, Azerbaijan, Belarus, Georgia, Kazakhstan, Moldova, Russia and Ukraine are allowed to enter the country without the need of issuing visa (Welcome Uzbekistan, 2016).

\section{The World Bank and Tourism Development}

The World Bank showed commitment to the tourism sector in the developing countries through providing funds and/or technical assistance and advisory. This commitment saw its golden age during the 1970s, particularly with the establishment of the Tourism Projects Department (TPD) in 1969. The department was established to support tourism sector in the client countries. However, 9 years later, the world bank decided to close the Tourism Projects Department. The reasons were mainly attributed to the high cost of the manpower and difficulties in coordination resulted of the complexity of the projects. In addition, the ultimate users of the investments were said not to be poor people (Hawkins and Mann, 2007). At the time the department was closed, 18 tourism projects were supported in 14 different countries. 
In their study, Hawkins and Mann (2007) reviewed over 300 projects to examine to the role that the World Bank played since the mid-60s in tourism development. The study suggested that the Bank's lending policy experienced a shift from macro to micro development. The study pointed out that since 1980s, the World Bank dropped its engagement in tourism activity, this disengagement is an institutional millstone to overcome (Hawkins and Mann, 2007).

Uzbekistan is among the Lower-middle-income economies (The World Bank 2016b). According the Bank's classifications of countries, Uzbekistan is among the Blend countries. These countries are considered financially creditworthy and therefore are eligible for International Development Association (IDA) loans and also for the International Bank for Reconstruction and Development (IBRD) loans (The World Bank, 2016d).

The Word's Bank commitments offered to Uzbekistan through the lending program reached 550 million US\$ in 2015 (The World Bank 2016c).

According to the World Bank, "the Bank's support has been focused on improving people's livelihoods, supporting the modernization of the country's social sectors and infrastructure, and sharing its knowledge and experience with the government and people of Uzbekistan." (The World Bank 2016c)

Since Uzbekistan joined the World Bank in 1992, 48 project have been launched. Of these projects, 21 projects are still active, and 18 projects are closed (completed). The rest are dropped (7) and expected to be implemented ( 2 projects). By reviewing the active and closed projects, that is, the projects that are being currently implemented and those which have been completed, it is interesting to find out the none of the projects have tourism as a main theme (see table no.1).

The active and closed projects seem to target mainly the development of infrastructure (e.g. Roads development), the resources management (e.g. Water supply, electricity), the industrial enterprises (e.g. Cotton industry) and the essential services (e.g. Heath system, education).

\begin{tabular}{|c|c|c|}
\hline Project title & Status & Year \\
\hline Modernizing Higher Education Project & Active & 2016 \\
\hline Integrated Single Window Office for Social Assistance and Employment & Active & 2015 \\
\hline Regional Roads Development Project & Active & 2015 \\
\hline Additional Financing for Bukhara and Samarkand Sewerage Project & Active & 2015 \\
\hline Pap-Angren Railway & Active & 2015 \\
\hline Improving Pre-primary and General Secondary Education Project & Active & 2014 \\
\hline South Karakalpakstan Water Resources Management Improvement & Active & 2014 \\
\hline Horticulture Development Project & Active & 2014 \\
\hline Additional Financing Energy Efficiency - Industrial Enterprises & Active & 2013 \\
\hline Additional Financing to Health System Improvement Project & Active & 2013 \\
\hline Sustainable Agriculture and Climate Change Mitigation Project & Active & 2013 \\
\hline Alat and Karakul Water Supply Project & Active & 2012 \\
\hline Additional Financing for the Second Rural Enterprise Support Project & Active & 2012 \\
\hline Advanced Electricity Metering Project & Active & 2012 \\
\hline Health System Improvement Project & Active & 2011 \\
\hline Talimarjan Transmission Project & Active & 2011 \\
\hline Syrdarya Water Supply Project & Active & 2011 \\
\hline Energy Efficiency Facility for Industrial Enterprises & Active & 2010 \\
\hline Ferghana Valley Water Resources Management Phase-I Project & Active & 2009 \\
\hline Uzbekistan Bukhara and Samarkand Sewerage Project & Active & 2009 \\
\hline Second Basic Education & Closed & 2009 \\
\hline Rural Enterprise Support Project Phase II & Active & 2008 \\
\hline Uzbekistan - Avian Influenza Control \& Human Pandemic Preparedness & Closed & 2007 \\
\hline Basic Education, Phase I & Closed & 2006 \\
\hline Global Alliance for Improved Nutrition - Nat'l Flour Fortification Program & Closed & 2004 \\
\hline Health 2 Project & Closed & 2004 \\
\hline Drainage, Irrigation \& Wetlands Improvement Project - Phase 1 & Closed & 2003 \\
\hline Bukhara \& Samarkand Water Supply Project & Closed & 2002 \\
\hline Rural Enterprise Support Project & Closed & 2001 \\
\hline Urban Transport Project & Closed & 2000 \\
\hline Financial Institution Building Project & Closed & 1999 \\
\hline Health Project & Closed & 1998 \\
\hline Enterprise Institution Building Project & Closed & 1998 \\
\hline Tashkent Solid Waste Management Project & Closed & 1998 \\
\hline Water Supply, Sanitation and Health Project & Closed & 1997 \\
\hline Pilot Water Supply Project & Closed & 1996 \\
\hline Cotton Sub-Sector Improvement Project & Closed & 1995 \\
\hline Rehabilitation Project & Closed & 1995 \\
\hline Institution Building Technical Assistance Project & Closed & 1993 \\
\hline
\end{tabular}

Table 1. World Bank's Development Projects in Uzbekistan Source: The World Bank (2016c). 
Till the moment, there has not been any project with the target to develop the tourism sector in Uzbekistan. Yet, taking into consideration the interdisciplinary nature of tourism, the outcomes of some projects that are not related to tourism may have indirect impact on the tourism development in the country. For instant, the adequate infrastructure is one of the main elements of any tourism destination. the "Regional Roads Development Project" approved by the World Bank in 2015 aims to improve the efficiency for transport infrastructure. According to a survey conducted as a part of the project, local communities recognize the positive role of the project in the "development of the tourism industry with forward linkages to other well-established sectors, particularly textiles and handicrafts" (The World Bank, 2015a: 64). An earlier project entitled the "Urban Transport Project" was approved in 2000 and aimed to provide "efficient and sustainable urban passenger transport services in Samarkand, Namangan, Bukhara, Nukus and Almalyk" (The World Bank, 2000: 23) A similar project approved 2015 addressed to transportation market in Uzbekistan and aimed to "enhance the efficiency of transport services into and out of the Uzbek part of the Ferghana Valley" (The World Bank, 2015b:4).

Researcher noted that human resources in Uzbekistan should be developed to ensure the quality of tourism services (Airey and Shackley, 1997, Baum and Thompson, 2007 Kapiki and Tarikulov, 2014). In addition, there is an urgent need in Uzbekistan for qualified personnel armed with knowledge to manage the tourism businesses (UNDP, 2007). The most recent project approved by the World Bank in April 2016 has the improvement of the quality of higher education as its main objective. According to the Project Appraisal Document, "since the mid2000s, Uzbekistan's economy is shifting out of agriculture into services. Nearly 80 percent of newly created jobs are in the service sector, which will create demand for a highly skilled workforce" (The World Bank, 2016e: 56). The service sector, and more specifically, the tourism sector depends mainly on human performance, in this regard, well trained and highly educated workers and employees have undoubtedly a pivotal role in the competitiveness of the tourism sector in the country. It can be presumed therefore, that "Modernizing Higher Education Project" may also have its indirect positive impacts on the tourism industry in the country.

The World Bank role is not restricted to financial support, technical assistance and advisory is also considered an important part of the bank's activity to help governments identifying opportunities and transforming them to tool of development. For instant, jointly with the International Finance Corporation (IFC), the world bank prepared an assessment report and presented it to the government in 2013. The report, entitled "Transforming Tourism Opportunities in Uzbekistan," was intended to assist the government in its efforts to lunch a long-term development strategy (World Bank, 2015c).

\section{Discussion and Conclusion}

This paper attempted to provide insights on the extent to which international organizations such as the World Bank contribute to the tourism development in an important emergent tourist destination in Central Asia. Researchers noted the scarcity of research on the role of external, that is, non-national organizations in the development of tourism industry (Hawkins and Mann, 2007). Therefore, this paper is intended to contribute to the body of knowledge in this direction.

The richness of Uzbekistan historical, natural and cultural sites and the relatively adequate infrastructure may pose tourism sector in the head of the most important income-generating sectors in the country. To achieve that, foreign capital is needed. Yet, tourism industry in Uzbekistan is apparently not among the priorities of the World Bank's development projects. Loans offered by the International Development Association (IDA) and the International Bank for Reconstruction and Development (IBRD) are mainly related to the infrastructure, resources management, industrial enterprises and essential services. It can be argued that the missing of a comprehensive tourism policy in Uzbekistan is one of the potential reasons why the sector in absent on the World Bank's agenda.

Central Asia States (CAS) are among the emerging destinations that, if the opportunities well-used, may attract larger numbers of international arrivals in the future. The recent integration of the CAS with international economy after the collapse of the former Soviet Union and the relatively new connections with international organizations might be among the reasons why tourism is still in its infantile stage in these countries.

It is hoped that the findings of this paper would encourage tourism planners in Uzbekistan reevaluate their connections with the international organizations to maximize their role in implementing projects that would contribute to the tourism development in the country.

The present paper is based mainly on secondary data through reviewing the World Bank's published reports related to the approved development projects in Uzbekistan. Obtaining primary data from tourism experts and tourism planners from both the public and the private sector would provide deeper insights on the topic. In addition, future studies may approach this topic through examining the role of other external (non-national) organizations in tourism development in the country such as the European Union and the Arab league.

\section{References}

- Agzamov, S, \& Tashmuratov T., 1995. Perspectives of Development of International Tourism in Uzbekistan Tashkent State Economics University, Tashkent. 
- Airey, D., \& Shackley, M., 1997. “Tourism development in Uzbekistan”. Tourism Management, 18(4), 199208.

- Ayres, R., 2000. "Tourism as a Passport to Development in Small States: Reflections on Cyprus". International Journal of Social Economics, 27(2),114-133.

- $\quad$ Baum, T. \& Thompson, K., 2007. "Skills aLabour Markets in Transition: A Tourism Skills Inventory of Kyrgyzstan, Mongolia and Uzbekistan”. Asia Pacific Journal of Human Resources, 45(2), 235-255.

- de Kadt, E., 1979. Tourism: Passport to Development, Oxford University Press, Oxford.

- Hawkins, D. E., \& Mann, S., 2007. “The World Bank's Role in Tourism Development”. Annals of Tourism Research, 34(2), 348-363.

- Kantarci, K., 2007a. "Perceptions of Foreign Investors on the Tourism Market in central Asia Including Kyrgyzstan, Kazakhstan, Uzbekistan, Turkmenistan”. Tourism Management, 28(3), 820-829.

- Kantarci. K., 2007b. "The Image of Central Asia Countries: Kyrgyzstan, Kazakhstan, Uzbekistan, and Turkmenistan". Tourism Analysis 12, 307-318.

- $\quad$ Kapiki, S. T. \& Tarikulov, M., 2014. "Development Prospects of Uzbekistan's Tourism and Hospitality Industry by Utilizing the EU Experience". in Proceedings of the International Conference on Tourism Milestones - Preparing for tomorrow, Sharjah, United Arab Emirates

- Kurzman, C., 1999. “Uzbekistan: The Invention of Nationalism in an Invented Nation”. Critique: Critical Middle Eastern Studies, 8(15), 77-98.

- Sancar, M. F., Kıngır, S. and Soyalın, M., 2015. "Orta Asya Türk Devletleri ile Türkiye Arasındaki Turizm Potansiyeli ve Ekonomi Açısından İncelenmesi”. In Proceedings of International Conference On Eurasian Economies (291-297), 9-11 September, Kazan-Russia.

- The Centre for Co-operation with the Economies in Transition, 1996. Investment Guide to Uzbekistan. OECD, Paris.

- $\quad$ The World Bank, 2000. Urban Transport Project. http://wwwwds.worldbank.org/external/default/WDSContentServer/WDSP/IB/2000/05/16/000094946 0004280530202 $\underline{0 / \text { Rendered/PDF/multi_page.pdf }}$

- $\quad$ The World Bank, 2015a. Regional Roads Development Project. http://wwwwds.worldbank.org/external/default/WDSContentServer/WDSP/IB/2015/06/08/090224b082f02167/1_0/Ren dered/PDF/Uzbekistan000R0Development0Project0.pdf

- The World Bank, 2015b. Pap-Angren Railway. http://wwwwds.worldbank.org/external/default/WDSContentServer/WDSP/IB/2015/01/28/000470435 2015012808484 8/Rendered/PDF/880150PAD0P146010Box385411B00OUO090.pdf

- $\quad$ The World Bank, 2015d. World Bank Group - Uzbekistan Partnership: Country Program Snapshot. https://www.worldbank.org/content/dam/Worldbank/document/Uzbekistan-Snapshot.pdf

- $\quad$ The World Bank, 2016a. World Development Indicators. http://data.worldbank.org/country/uzbekistan\#cp_wdi

- The World Bank, 2016b. Country and Lending Groups. http://data.worldbank.org/about/country-andlending-groups

- The World Bank (2016c). Projects \& Programs. http://www.worldbank.org/en/country/uzbekistan/projects

- The World Bank, 2016d. How does the World Bank classify countries? https://datahelpdesk.worldbank.org/knowledgebase/articles/378834-how-does-the-world-bank-classifycountries

- The World Bank, 2016e. Modernizing Higher Education Project. http://wwwwds.worldbank.org/external/default/WDSContentServer/WDSP/IB/2016/04/11/090224b084282e47/1_0/Ren dered/PDF/Uzbekistan000M0r0Education0Project0.pdf

- UNDP (2007). Uzbekistan`s Tourism Sector - an Unrealized Potential. 2(9) Policy brief. UNDP Uzbekistan.

- Welcome Uzbekistan, 2016. Visa. http://welcomeuzbekistan.uz/en/useful/visa.html

- World Travel and Tourism Council, 2015. Travel \& Tourism Economic Impact 2015 Uzbekistan. https://www.wttc.org//media/files/reports/economic\%20impact\%20research/countries\%202015/uzbekistan2015.pdf 